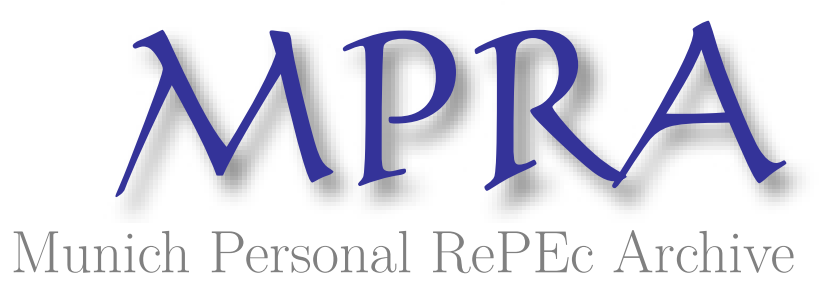

\title{
Medicinal and Aromatic Plants \\ Cultivation in Bihar, India: Economic Potential and Condition for Adoption
}

Singh, K.M. and Jha, A.K.

ICAR-RCER, Patna, S.G.I.D.T., Patna

14 February 2008

Online at https://mpra.ub.uni-muenchen.de/47091/

MPRA Paper No. 47091, posted 20 May 2013 20:34 UTC 


\title{
Medicinal and Aromatic Plants Cultivation in Bihar, India: Economic Potential and Condition for Adoption
}

\author{
K.M. Singh ${ }^{1}$ and Awadhesh K Jha ${ }^{2}$
}

The history of cultivation and use of medicinal and aromatic plants (MAPs) in India is quite ancient. In one way or other, many of these plants have been an integral part of Indian health and livelihood systems. The MAPs provide opportunities for developing a variety of safe and cost effective, prophylactic, and curative medicines for a number of maladies. It is estimated that the primary health care of over 80 per cent of the world's population still depends on plant based traditional medicines (WHO, 2002). Growing consciousness about health and side effects of modern medicines has again set the stage for innovation and use of herbal medicines. The global market for herbal products is continuously expanding and it is expected to touch the mark of US\$ 5 trillion by the year 2050, from the US\$ 62 billion in 2004 (Purohit and Vyas, 2004). Despite being a major player, the share of India in global trade of MAPs is merely 0.5 per cent, whereas the countries, like China exports plants and raw drugs, therapeutics and other MAPs worth Rs 18,000 crores annually (Singh, 2005). India has one of the richest sources of many kinds of MAPs but it has achieved only a limited success in tapping the potentials of these plants because of low level of awareness among the farmers about the economic potential and returns (Purohit, 2004) from these plants.

\section{Economic Potentials of MAPs}

Estimates show that that the potential returns to farmer from cultivation of medicinal plants are quite high (Nautiyal, 1995; Rao and Saxena, 1994). The cultivation of certain high altitude Himalayan herbs could fetch products price anywhere between Rs. 7,150 to 55,000 per hectare (Nautiyal, 1995)2. Although it is not clear that at which stage of the marketing chain these prices are paid but it is obvious that despite varying returns production of medicinal plants could raise the income of farmers to a great extent. Rao

\footnotetext{
${ }^{1}$ Head, Division of Social Sciences, ICAR-RCER, Patna-800 014, India

${ }^{2}$ Assistant Professor, Department of Dairy Business Management, SG Institute of Dairy Technology, Patna
} 
and Saxena (1994) reported an average annual income of Rs. 120,000 per hectaec through mixed cropping of high altitude medicinal herbs. Even the low altitude MAPs assume signicant economic importance and can be judiciously cultivated to bridge the current gap between demand (40 thousand tons) and supply (20 thousand tons) is estimated to be 40,000 to 200,000 tons, which is expected to rise to 152,000 to 400,000 tons by 2005 (Planning Commission, 2000 \& CRPA, 2001) to improve the income and status of the rural farm household.

The demand for medicinal plants in India, to meet both domestic and export market, comprising of 162 species, is expected to increase at about 15 to $16 \%$ between 2002 and 2005 (CRPA, 2001). Evidence shows that the total domestic potential for crude drugs and oil extracts in India is worth Rs 3 billion, of which the requirements of over-the-counter products. Including cosmetics and ethical and classical formulations, are of Rs 1.2 billion each; whereas traditional medicines of Vaidyas and hme reedial formulations acount for about Rs. 400 million and 200 million, respectively (Exim Bank, 1997). Medicinal plants cultivation and management therefore, could become highly remunerative both in financial and economic terms for the small-scale growers. Not only the plants are in increasing demand by major herbal drug industries as an essential raw material of their drugs, but also its collection, production, processing, packaging and transportation requires high labor input, which can create job lead growth in job-starved state of Bihar. Collection from wild and selective harvesting in addition to primary processing is mostly done manually, and even at the secondary and tertiary levels, MAPs have substantial labour requirements. Moreover, not only do MAPs-based industries expand jobs, enhancing traditional uses through value added processing can increase cash earnings to the local people.

Expanding world markets for MAPs are further opening up new vistas of opportunities. So far, Germany has been the largest market for MAPs but now the European market is growing rapidly at the rate of over $4 \%$ per annum for herbal remedies and even faster for herbal supplements. The size of European market for herbal supplements is estimated at over US\$ 2.7 billion and for herbal remedies, a further US\$ 0.9 billion. The US herbal 
market is, though nearing saturation but it is expected to peak at US\$ 6-8 billion in the next few years. Thus the global demand for medicinal plants is expected to expand continuously, fuelled by the growth of sales of herbal supplements and remedies. Their basic uses in medicine will continue in the future, as a source of therapeutic agents, and as raw material base for the extraction of semi-synthetic chemical compound such as cosmetics, perfumes and food industries. All these pose a unique opportunity for India to penetrate deep into the world market to harness the untapped potentials of MAPs.

\section{Steps taken}

Taking cognizance of such enormous and grossely untapped potentials of MAPs, the Government of India has accorded high priority to the R\&D and cultivation of MAPs in the country. A number of techniques have been developed to increase the quality and yield of many of the cultivated species. It is estimated that Indian public sector research institutions have developed standardized practices for the propagation and agronomy of a total of about 40 species.

Much of the research progress to date has resulted from the decision of the Indian Council for Agricultural Research (ICAR) to establish an All-India Coordinated Research Project on Medicinal and Aromatic Plants (AICRPMAP), in 1972, under the auspices of the National Bureau of Plant Genetic Resources (NBPGR). Efforts have mainly focused on the development of agro-technology techniques, including propagation methods for medicinal and aromatic plants. Aromatic plants have however tended to receive more attention, perhaps because their market values are in general more widely known. ICAR works through a network of research stations, including the National Research Centre for Medicinal and Aromatic Plants located in Anand, Gujarat, which specializes in domestication, and has created structural links between the NBPGR and its Plant Breeding Division in order to develop improved varieties of some of the medicinal plant species used in allopathic preparations.

The Council for Scientific and Industrial Research (CSIR), has also played a significant role with regard to cultivation of medicinal plants, by establishing the Central Institute of 
Medicinal and Aromatic Plants, in Lucknow (CIMAP). CIMAP is now an eminent institution in India focusing on agro-technology as well as basic studies; improvement and enhancement of the resource base, and chemistry and related research regarding product development from plants.

Apart from these, the Government of India launched a scheme for the development of MAPs during the $8^{\text {th }}$ Five Year Plan (1992-97). The scheme attempted to include production quality planting materials, establihment of herbal gardens and regional analytical laboratories with the help of 16 state agricultural universities, state horticulture and agriculture departments, regional research laboratories and the International Crop Research Institute for the Semi-Arid Tropics (ICRISAT). There are other actors also who are playing important role in the development and production of MAPs. For instance, Ministry of Health \& Family Welfare (Department of ISM\&H) and a number of private agencies/ companies are also encouraging development of agrotechnique for important species with the help of Govt/semi-government organisations having expertise and infrastructure for this work.

In addition, the centre and state (governments) have made provisions for adequate financial supports in the forms of subsidies and loans to the growers of MAPs throgh various agencies like National Medicinal Plant Board (NMPB), National Bank for Agricultural and Rural development (NABARD), Agricultural and Processed Food Products Export Development Authority (APEDA), National Horticultural Board (NHB), Agri-Export Zone (AEZ), etc. The NMPB supports several promotional as well as commercial programmes and provides cent per cent financial assistance to promote MAPs in the country. The Integrated Development of Medicinal and Aromatoc Plants, Ministry of Agriculture is also a commendable step that supports production to processing as well as training of the farmers with limited financial assistance.

\section{MAPs in Bihar}


Realizing the vast untapped potentials of MAPs and impediments in their development, Bihar Agricultural Management and Training Institute (BAMETI) has made remarkable efforts to promote MAPs in the state under ATMA, Patna. ATMA has follwoed a systematic approach while taking MAPs for pilot testing. It made assessement about the local conditions and requirements, and demand for MAPs; strengthened capacity by traing various stakeholders; played role in supporting individuals and institutions; developed relevant literature in local language; emphasized on group approach by organizing the growers; encouraged cultivation through the organized sector with linking the unorganized farmers; and evolved a pricing mechanism with buy back arrangement with partner industry under public-private partnership(PPP).

\section{Current status}

Table 1 shows details of area, production and yield of various aromatic plants in 2007-08 in Bihar. It is obvious that cultivation of medicinal plants is quite limited and only 2410 ha of land was under cultivation of these plants. Among different commercially growing species of aromatic plants, mentha and lemon grass have emerged as the major players and shared 95 per cent in total area and production of aromatic plants in the state.

Table 1. Details of aromatic crops being grown in Bihar (2007-08)

\begin{tabular}{|l|c|c|c|}
\hline MAPs & $\begin{array}{c}\text { Area } \\
\text { (ha.) }\end{array}$ & $\begin{array}{c}\text { Total oil } \\
\text { production (tons) }\end{array}$ & $\begin{array}{c}\text { Oil yield } \\
\text { (kg./Ha.) }\end{array}$ \\
\hline Lemon grass & 185 & 25.90 & 140 \\
\hline Java citronella & 38 & 4.75 & 125 \\
\hline Mentha & 2100 & 252.00 & 120 \\
\hline Palma rosa & 20 & 2.00 & 100 \\
\hline Tulsi (basil) & 32 & 3.20 & 100 \\
\hline Jama rosa/CN-5 & 35 & 5.25 & 155 \\
\hline
\end{tabular}

As far as the status of medicinal plants in Bihar is concerned (table 2), it is still negligible. Merely 380 tons of medicinal plant produces are being produced over 95 ha of land. Evidence indicates that commercial cultivation of some of the species of MAPs are picking up in the state but still a lot of efforts are required to observe the real impacts of their cultivation (Singh, 2007). Impetus in terms of planning, funding, production, 
processing, and strong market linkage is essential to harness the potentials of commercial production of MAPs.

Table 2. Details of medicinal crops being grown in Bihar(2007-08)

\begin{tabular}{|l|c|c|c|}
\hline MAPs & Area (ha.) & $\begin{array}{c}\text { production } \\
\text { (ton) }\end{array}$ & $\begin{array}{c}\text { yield } \\
\text { (kg./Ha.) }\end{array}$ \\
\hline Safed musli (Chlorophytum borivillinum) & 16 & 24.0 & 1500 \\
\hline Kalmegh (Andrographis penniculata) & 15 & 45.0 & 3000 \\
\hline Sarpgandha (Rauwolfia serpentina) & 12 & 19.2 & 1600 \\
\hline Shatawar (Asparagus racemosus) & 17 & 127.5 & 7500 \\
\hline Buch (Acorous calamus) & 6 & 19.2 & 3200 \\
\hline Jatropha (Jatropha curcas) & 29 & 145.0 & 5000 \\
\hline
\end{tabular}

\section{Economics of MAPs vis-à-vis other field crops}

The comparative economics of MAPs and a few major field crops reveals that returns from MAPs are comparable with any of the field crops. The returns from medicinal plants like safedi musali, sarpgandha, satawari, are fairly high. Similarly, returns from aromatic plants like lemon grass, rosa species, etc. are yield better returns and also their cost of cultivations are lower in comparasion to many of the field crops. The irony is that over 80 percent of the Bihar population is smallholder ( $<2 \mathrm{ha}$ of land size) and therefore, they generate very small marketable surplus. Such a small scale production and tiny marketable surplus fail to attract mrakets.

Table 3. Comparative economics of major crops in Bihar

\begin{tabular}{|l|l|l|l|}
\hline Crops & Cost of & Gross & Net \\
\hline
\end{tabular}




\begin{tabular}{|l|c|c|c|}
\hline & $\begin{array}{c}\text { cultivation } \\
\text { (Rs/ha) }\end{array}$ & $\begin{array}{c}\text { income } \\
(\mathbf{R s} / \mathbf{h a})\end{array}$ & $\begin{array}{c}\text { income } \\
\text { Rs/ha/ } \\
\text { year }\end{array}$ \\
\hline Lemon grass & 22500 & 42000 & 19500 \\
\hline Java citronella & 19500 & 33750 & 14250 \\
\hline Mentha & 20500 & 36000 & 15500 \\
\hline Palma rosa & 22500 & 40500 & 18000 \\
\hline Tulsi (basil) & 11500 & 20000 & 8500 \\
\hline Jama rosa/CN-5 & 25000 & 50375 & 25375 \\
\hline $\begin{array}{l}\text { Safed musli (Chlorophytum } \\
\text { borivillinum) }\end{array}$ & 65000 & 102000 & 37000 \\
\hline Kalmegh (Andrographis penniculata) & 58000 & 65000 & 7000 \\
\hline Sarpgandha (Rauwolfia serpentina) & 30000 & 64000 & 34000 \\
\hline Shatawar(Asparagus racemosus) & 25000 & 50000 & 25000 \\
\hline Buch (Acorous calamus) & 25000 & 40000 & 15000 \\
\hline Jatropha (Jatropha curcas) & 17000 & 30000 & 13000 \\
\hline Paddy-wheat* & 42947 & 58853 & 15906 \\
\hline Sugarcane* & 48343 & 84323 & 35980 \\
\hline
\end{tabular}

* Source: Mittal and Singh, 2007.

\section{Strategies to Be Followed}

Though commercial cultivation of some of the species of MAPs are picking up in the state but still a lot of efforts are required to observe the real impacts of their cultivation (Singh, et al. 2007). Impetus in terms of planning, funding, production, processing, and strong market linkage is essential to harness the potentials of commercial production of MAPs.

Formal bio-partnerships between certified farmers and Ayurvedic pharmaceutical companies, like Baidyanath Ayurved Bhawan, Patna; Ayurved Shri Herbals Ltd, Ahmedabad, Fragrance Herbs, Patna needs to be explored. The arrangement should ensure farmers with a guaranteed market and a fixed fair price for their harvest, in exchange for exclusive rights to the produce as the sole buyer.

The other agencies like departments of Forest, Agriculture, Horticulture, Health and Family Welfare can come together to offer technical, market related and other input 
supply services to the various stake holders so that sector as a whole can grow and dependence on outside sources for primary health care is minimized.Use of farmer Interest Groups for dissemination of technology and market information can also be explored in the state.

\section{Reference}

World Health Organization (WHO). 2002. Traditional Medicine Strategy 2002-2005. Website: www.who.int/medicines/library/trm/trm_start_eng.pdf.

Purohit, S.S. and S.P, Vyas. 2004. Marketing of medicinal and aromatic plants in Rajasthan, National Consultative Workshop on Medicinal and Artomatic Plants, held at GBPUAT, Pantnagar.

Singh, H. P. 2005. Promotion of medicinal and aromatic plant sector in Uttarakhand. Need of hour. National Consultative Workshop on Medicinal and Artomatic Plants, held at GBPUAT, Pantnagar.

Planning Commission, 2000. Report of the Taskforce on Medicinal Plants in India. Planning Commission, Government of India, Yojana Bhawan, New Delhi, India

Export Import Bank of India. 1997. indian Medicinal Plants: A Sector Study . Export Import Bank of India, Occasional Paper No. 54.

Singh, K. M., Umesh Singh' and Pushpa Singh 2007. A Study on Role of ATMA, Patna in Development of Supply Chain for Medicinal Plants in Patna District, Bihar (India). Status Paper-3, ATMA, Patna.

Singh, K.M., 2009. Scope of Medicinal and Aromatic Plants Farming in Eastern India (Feb 19, 2009). Available at SSRN: http://ssrn.com/abstract=2019789 or http://dx.doi.org/10.2139/ssrn.2019789 